\title{
Six learning theory perspectives on a Web-based learning environment
}

\author{
M. R. de Villiers \\ School of Computing Unisa \\ University of South Africa \\ Pretoria, South Africa. \\ E-mail: dvillmr@unisa.ac.za
}

\section{J. C. Cronje}

Faculty of Education

University of Pretoria

Pretoria, South Africa.

E-mail: jcronje@up.ac.za

\begin{abstract}
The University of Pretoria offers a masters degree in computer-integrated education, incorporating a module called Internet-based learning. This module uses constructivist and collaborative techniques via web-based distance learning to portray aspects of a real classroom in a web-environment. The Hexa-Metamodel $(\mathrm{HCMm})$ is a synthesis of paradigms of contemporary learning and instructional theory, comprising six elements relevant to e-learning events and environments, namely: (i) cognitive learning theory, (ii) constructivism, (iii) components of instruction, (iv) collaborative learning, (v) customisation, and (vi) creativity. Using the HCMm as an evaluation approach, this article investigates the module's webclassroom and collaborative environment to examine conformance to contemporary learning theories. We present findings of a survey among students, identify strengths and their causes, and note problems and recommendations.
\end{abstract}

\section{INTRODUCTION}

The University of Pretoria offers a M.Ed. in Computer-integrated Education, including a module called Internet-based Learning, which is taught via distanceeducation on the Internet (Cronjé 2001). This article describes the module and its web-based classroom, and presents findings from a survey of learners. As an evaluation approach, the Hexa-C Metamodel (HCMm) - a synthesis of paradigms of contemporary learning and instructional theory (De Villiers 1999, 2000, 2003) was used to investigate to what extent the instructional design of the module implemented elements of the HCMm, namely: (i) cognitive learning theory, (ii) constructivism, (iii) components of instruction, (iv) collaborative learning, (v) customisation, and (vi) creativity.

The first author took the module as an external student and also evaluated it, conducting qualitative analysis by surveying the 22 students of two successive 
presentations. The co-author is the module leader, who provided information from other presentations. In the next section we describe Internet-based Learning and its web-environment, before outlining the research methods and the HCMm. Using the HCMm elements as headers, we then give findings of the investigation into course content and methods from a perspective of learning and instructional theory. The final focus is on lessons learned, presenting strengths, problems and recommendations.

\section{Module content}

Internet-based Learning is presented immersively on the Web, providing course information on its website and handling communication electronically. The environment employs the metaphor of a conventional junior school classroom (Cronjé 2001) and uses a problem-based approach to teach theoretical and practical expertise for using the Internet to present, manage and facilitate resource-based learning and distance education. Coursework involves individual synthesis and analytic assignments, co-operative tasks and a whole-group collaborative multimedia project. The exam is an individual project worth 50 per cent of the grade.

\section{Module context}

The M.Ed. (Computer-integrated education) is a tutored contact-degree, but Internet-based Learning is offered via online distance education, so that its learnercum-educators can experience first-hand the situation of Internet-based learners (Cronjé and Clarke 1999). Students tackle tasks, working asynchronously from their homes or workplaces. Core information and instructions are on the website, supplemented with regular communication via an e-mail list, where the leader posts messages and students interact. Online chat sessions occur, but no face-toface meetings. Students post their work products on the Web and provide hyperlinks to their collaborative projects.

\section{Students}

Annual class size is approximately ten students, mainly aged 30-50. The two classes surveyed had a combined population of 22, thirteen females and nine males. Sixteen had honours degrees and six held masters or doctorates. Most were professional educators - teachers, lecturers, consultants and instructional designers. Three were fulltime students. The idea was for them to gain knowledge and skills in a situation that would help them empathise with the circumstances of their target learners. They did not all know one another. 


\section{DESIGN OF THE ENVIRONMENT}

\section{Design philosophy}

The design was based on a constructivist ethos, avoiding aspects that are instructivist/behaviourist. The module leader did not use packaged learning managements systems, but developed free working space using Dreamweaver and Frontpage as tools and Yahoogroups for communication. Students created personal websites on any server, using tools of their choice and linking to the home page.

\section{Generic classroom}

Cronjé (2001) and Cronjé and Clarke (1999) describe Internet-based Learning's electronic classrooms based on the junior school metaphor, an analogy chosen to provide informality. While acknowledging that virtual environments cannot replicate contact-teaching, the instructor-designer set out to portray the objects and events of a typical classroom. The website represented the physical and visual aspects, while the e-mail list provided instructional and conversational interactions.

\section{A particular web-classroom}

Assignments change each year, and the home page undergoes updates, although classroom objects remain standard. Figure 1 shows the home page of a webclassroom with:

1. Buttons, which linked to outcomes, tasks, timetable, class list, references, etcetera. Clicking on these provided information similar to lists on notice boards or printed material. Others accessed the objectives, course topics and grading system. The website was augmented with 'extra lessons' by links to HTML tutorials.

2. The poster wall, linked to projects by former students and current students' 'posters'.

3. A blackboard implemented as a graphics file. Students accessed and edited this 'chalkboard', simulating graffiti.

4. The central region containing students' 'desks'. Figure 2 shows how some students replaced the generic desks with personalized representations, linked to their own website or metaphorical 'study'. They progressively 'filled their desks' by creating icons and linking them to associated objects, namely their 'ears' (e-mail address); 'utility bag' (links to tools and databases); 'textbooks' (useful resources); 'work' (relevant work done in their studies/employment); 'hobbies' (personal information); 'class work' (assignments); and 'portfolio' (link to their examination project) (Cronjé 2001). 


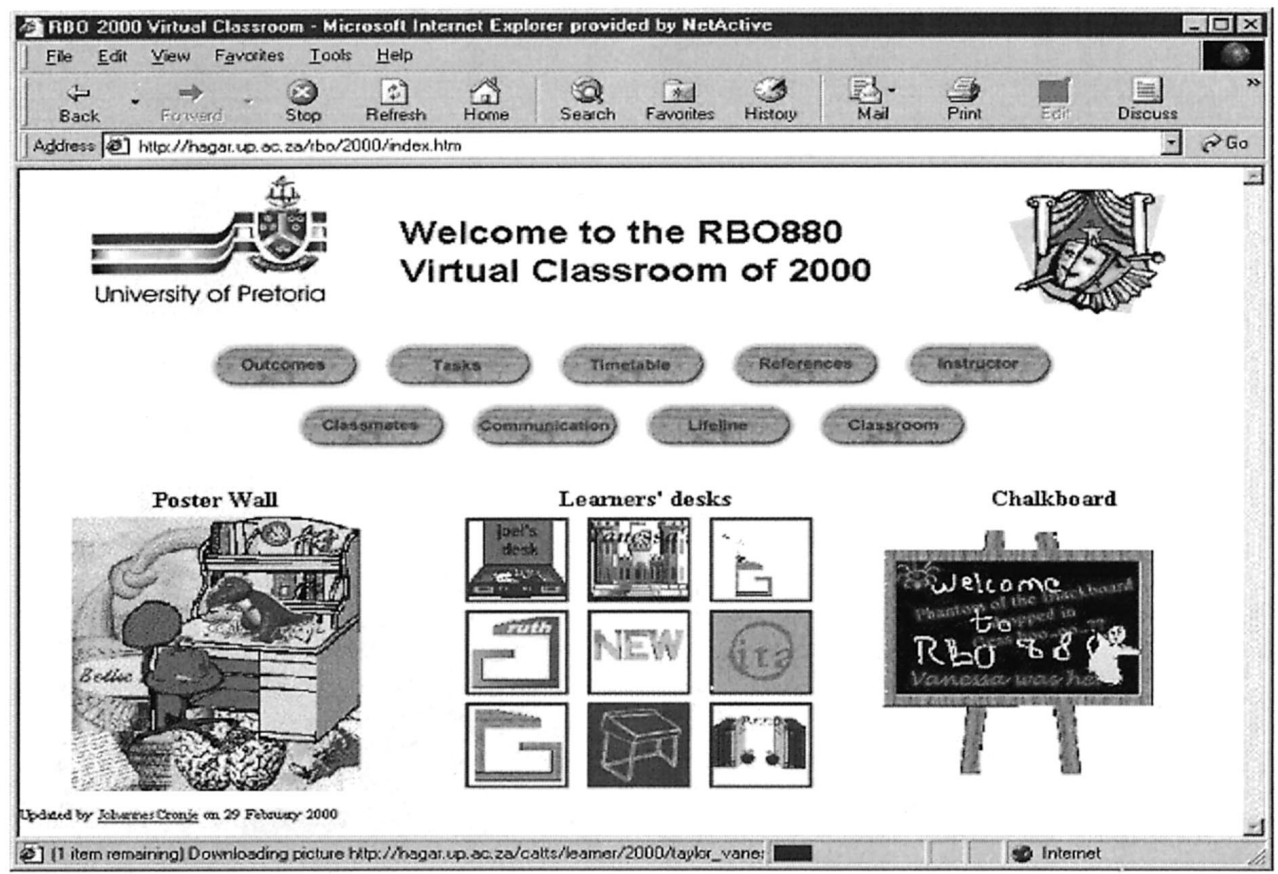

Figure 1: Homepage of an RBO-classroom website
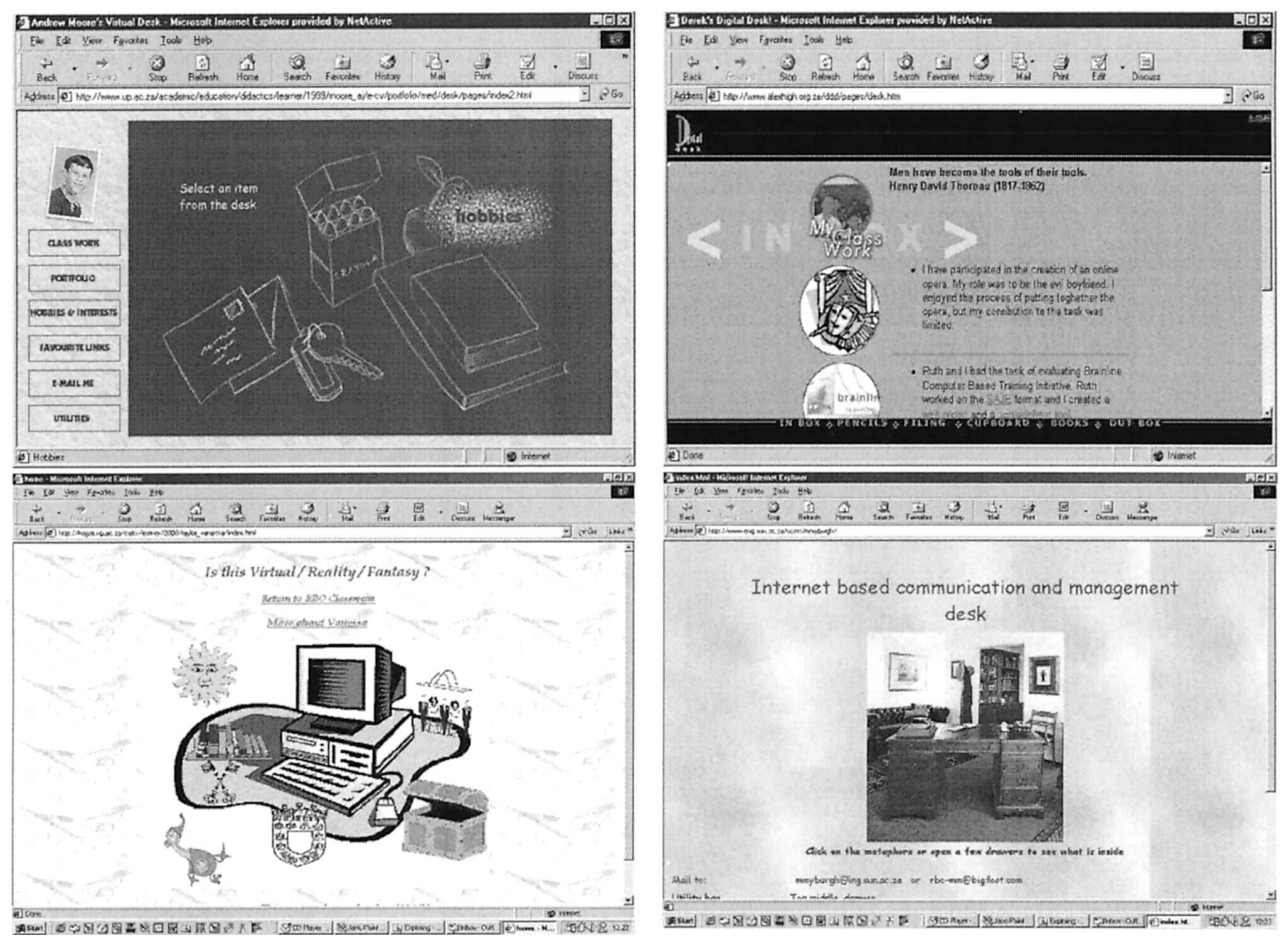

Figure 2: Desk websites of four learners 


\section{Class communication}

Communication with the leader and fellow-learners occurred via the dedicated email list. Lively debate, questions and answers, humour and chit-chat and analytic discussions ensued within this forum, substituting face-to-face conversation (Cronjé and Clarke 1999). Initial presentations lacked real-time interaction, which was subsequently introduced by Chat facilities.

\section{Class tasks}

Each presentation commenced with individual tasks for familiarisation. Students browsed in the web-classroom; they built and arranged their desks, and introduced themselves electronically. Then major collaborative projects commenced, involving multimedia developments such as a 'virtual opera', a 'university rag procession' and an online 'Survivor' game. Communication occurred as rules and roles were identified. This was followed by tasks for cooperative pairs. Finally, students tackled individual exam projects, uploading their proposals for scrutiny and 'discussion', and then moving on to information gathering and presentation in their web portfolios.

\section{RESEARCH METHODS}

The evaluation was conducted from a learning-theory perspective, investigating how the module implemented tenets of contemporary learning theory. Triangulated qualitative and quantitative research methods were used in a learner evaluation, the main data collection method being a questionnaire survey among the thirteen students of one presentation and nine from the next. As an evaluation approach, we used the Hexa-C Metamodel (HCMm) framework (De Villiers 1999, 2000, 2003), termed 'Hexa' due to its six inter-related elements starting with ' $\mathrm{C}$ ' and 'Metamodel' because it is a synthesis. The elements are cognitive learning theory, constructivism, components of instruction, collaborative learning, customisation, and creativity. The HCMm suggests underlying foundations for e-learning artifacts, serving both as a design aid and an evaluation approach. (It was not used in the design of Internet-based Learning, which pre-dated the HCMm.) The HCMm takes cognisance of context, since the relationship between learning theory and appropriate practice differs from one situation to another, and it is not the intention that each C-element be explicitly applied in each. The HCMm has been used in evaluating various learning systems and events, for example, a computerbased lesson and a multi-disciplinary problem-based learning experience where computers were used as tools (de Villiers 2000; de Villiers and Queiros 2003).

There were 40 groups of questions, many of them open-ended, requiring substantiated responses. Some investigated conformance to a particular C-element; others were generic, but their responses were analysed to note implementation of HCMm elements. Only limited percentages and statistics were determined, due to 
the small population. We also conducted 'virtual' observation and reflective research into artefacts representing other years - their websites, work products and mailing lists, which generated descriptive data.

\section{FINDINGS OF THE EVALUATIONS}

This section is structured under the six C's, introducing each, then setting out findings regarding its implementation in the module. We show strengths of conformance to the HCMm elements where appropriate, and point out problems identified.

\section{Cognitive learning theory}

Cognitive psychology views learning as a process that supports cognition, formation of internal knowledge structures and retention. Cognitive learning theory posits that cultivating cognitive processes is as important as generating products. It addresses issues such as critical thinking, metacognition, cognitive strategies, self-regulation, and integration of knowledge with prior learning (Gagné and Merrill 1990; Inhelder and Piaget 1958; Newell and Simon 1972; Osman and Hannafin 1992; Winn 1990). Survey questions addressed integration of new/prior learning, self-regulation, and cognitive-affective connections. Final performance scores were also noted.

\section{Integration of new with prior knowledge}

Internet-based Learning did not explicitly teach website creation, although the classroom had links to HTML tutorials and web-tools. Students entered with varying technological skills. Of the 22 , seven classified themselves as Internet novices (termed Group 1); eight had used websites (Group 2); and seven had previously constructed web pages (Group 3). Some backgrounds:

I'm a computer person, not an educator / I grew up with computer technology. /

I'm a conventional educator / no Internet expertise, no Web skills /

Combining my learning theory and knowledge of web-authoring was very relevant.

Novices expressed insecurity:

There is still basic knowledge one needs to master. /

The learning curve is very steep. / . . nerve wrecking . . . really tough /

A good way of learning, but it consumes time and energy. /

Frustration, irritation ... 
The students with initial low web skills undertook independent learning using the linked tutorials. 'Lifeline helpers', a buddy system of past students (see Lifeline button, Figure 1) offered further support. With determination, students bridged the gap:

Reading, reading, ... /Used the hyperlink references / HTML manuals /

Examined the work in previous classrooms / Trial and error on the technical things/

Yelling for help and using the lifeline helpers /

Desperation and self-discovery / Networking /

I asked, I experimented a lot. / If you persevere, you gain and retain.

By the end 17 students termed themselves confident web designers. Eight were keen to present web-based courses, some doing so immediately. The next subsection shows that the skills-gap was overcome.

\section{Academic performance}

We investigated final percentages. The group mean was exactly 73 per cent. With perseverance and hard work, Group 1 novices overcame the skills gap and attained a mean of 70.67 per cent against 72.14 per cent for Group 2 (had used websites) and 75.5 per cent for Group 3 (prior website development skills). Parametric comparison of these means in a one-way analysis of variance (ANOVA) showed that the three groups did not differ significantly $(p=0.350>0.05)$ w.r.t to mean final score. We also confirmed using a non-parametric method (Kruskal-Wallis one-way analysis of variance), that the difference was not significant $(\mathrm{p}=0.422$; chi-squared approximation).

\section{Cognitive-affective connection}

Affective issues influence cognitive processes (Price 1998). Students with lower technological backgrounds experienced stress. Table 1 lists thematically categorised responses to an open-ended question, regarding aspects which caused had anxiety. The p-values from Fisher's exact test indicate that occurrences of most of the anxiety-inducing aspects did not differ significantly between Groups 1, 2 and 3. The exception is frustration due to low skills, which was experienced by significantly more students $(\mathrm{p}=0.022<0.5)$ in Group 1 (novices).

The attrition rate - one third - was high. Those surveyed had completed the module; they were 22 of the 33 who had registered in the two years. Of the eleven who discontinued, five had merely visited the web-classroom and cancelled early, citing inadequate time:

I regret to announce my departure from this digital domain. My virtual self has been swamped by my REAL desk . . . / I just didn't realise the time and effort required. 
Table 1: Aspects of stress/anxiety

\begin{tabular}{|l|c|c|c|c|c|c|}
\hline & \multirow{2}{*}{$\begin{array}{c}\text { Number } \\
\text { of }\end{array}$} & \multicolumn{5}{|c|}{ Aspect that induced anxiety } \\
\cline { 3 - 7 } & learners & Overload & $\begin{array}{c}\text { Fast pace/ } \\
\text { inadequacy } \\
\text { due to low } \\
\text { skills level }\end{array}$ & $\begin{array}{c}\text { Technical } \\
\text { (software) }\end{array}$ & $\begin{array}{c}\text { Technical } \\
\text { (hardware) }\end{array}$ & $\begin{array}{c}\text { Deadlines/ } \\
\text { other } \\
\text { studies }\end{array}$ \\
\hline 1. Novices & 7 & 2 & 4 & 2 & 3 & 2 \\
$\begin{array}{l}\text { 2. Had used websites } \\
\text { 3. Had built websites }\end{array}$ & 8 & 2 & 1 & 1 & 1 & 3 \\
$\begin{array}{l}\text { Total } \\
\text { Fisher exact } \\
\text { p-value to compare } \\
\text { the groups }\end{array}$ & $\mathrm{n}=22$ & 8 & 5 & 3 & 3 & 5 \\
\hline
\end{tabular}

The other six had cancelled during the module, four for technological reasons and two for personal reasons.

With hindsight the module leader mused, 'Regarding the level of prior learning and the extent of work, I may have asked too much, too soon, contributing to attrition ....'

\section{Scheduling and self-regulation}

As professional educators, students felt the impact of workplace pressure. Issues that emerged from our inquiry into priorities and hindrances were pressure of time in balancing studies, career and family commitments, as well as technological aspects.

\section{Constructivism}

Constructivism (Bruner 1967; Duffy and Jonassen 1991; Jonassen 1999; Land and Greene 2000; Savery and Duffy 1995; Willis 2000; Winn 1992) relates to tenets such as knowledge construction, active learning, personal goals and multiple perspectives. Constructivist learning includes problem/project-based learning, open-ended learning environments, unsimplified tasks and integrated assessment. Constructivism is not direct instruction; rather, it entails setting up authentic environments and activities within real-world situated learning. It emphasizes collaborative activities and varied resources Table 2 shows how the web classroom implements Perkins' (1991a) facets of a learning environment in a constructivist manner and also outlines the connotations of each facet. The next subsections take certain constructivist tenets and discuss their implementation in the module. 
Table 2: Facets of the module?s constructivist environment

\begin{tabular}{|c|c|}
\hline $\begin{array}{l}\text { Facets of a learning environ- } \\
\text { ment (Perkins, 1991a) }\end{array}$ & Implementation in Internet-based Learning \\
\hline $\begin{array}{l}\text { Information banks } \\
\text { (resources of explicit informa- } \\
\text { tion) }\end{array}$ & $\begin{array}{l}\text { Web-based 'classroom' } \\
\text { Technology manuals, online tutorials and help facilities } \\
\text { 'Techie' friends }\end{array}$ \\
\hline $\begin{array}{l}\text { Symbol pads } \\
\text { (media for constructing and } \\
\text { manipulating symbols) }\end{array}$ & $\begin{array}{l}\text { Internet connections } \\
\text { Scanners } \\
\text { Keyboard and mouse, used to generate text, visuals, etc. }\end{array}$ \\
\hline $\begin{array}{l}\text { Construction kits } \\
\text { (software applications, tools } \\
\text { and apparatus) }\end{array}$ & $\begin{array}{l}\text { Web-authoring systems: HTML, Frontpage, Dreamwea- } \\
\text { ver, Netscape Composer, Shockwave, Arachnophilia } \\
\text { Graphics programs: Adobe, CorelPhotoshop, Paint- } \\
\text { ShopPro } \\
\text { Spreadsheets \&\#38; databases for manipulating vari- } \\
\text { ables and decision-making }\end{array}$ \\
\hline $\begin{array}{l}\text { Phenomenaria } \\
\text { (objects that present phenom- } \\
\text { ena) }\end{array}$ & $\begin{array}{l}\text { Internet and World Wide Web } \\
\text { Examples of previous students? work }\end{array}$ \\
\hline $\begin{array}{l}\text { Task managers } \\
\text { (that set tasks, guide, give } \\
\text { feedback) }\end{array}$ & $\begin{array}{l}\text { RBO online directives (in web-classroom and via e-mail) } \\
\text { Yahoo calendar, Yahoo chat }\end{array}$ \\
\hline
\end{tabular}

\section{Active learning, knowledge construction}

As students researched and developed products, they actively explored WWW resources and tools, finding information from multiple sources and perspectives. This necessitated top-down, just-in-time learning. Certain tasks entailed socially negotiated learning.

Construction in the module was transparent, in that students' websites and underlying code (HTML, etc.) were visible to peers, as were work products from previous years. Table 3 shows students' perceptions on constructivist aspects, indicating that three quarters experienced a 'very great' or 'great' extent of situated learning (17 students), discovery-learning (18), and active knowledge construction (17). The p-values in the final column, obtained from Fisher's exact tests, indicate no significant differences between Groups 1, 2 and 3 (raw scores of the groups were used in the analysis, but are not shown in the table). Impressions were:

A new universe to me - I LOVE the educator-as-learner experience. /

I had new ideas all the time - I enjoyed being challenged. /

I learn a lot because I can choose what I want to do. /

Experimentation and lack of boundaries. /

Pressure!! Lots, not as much external, but self-laden. 
Table 3: Constructivist aspects in RBO

\begin{tabular}{|l|c|c|c|c|c|}
\hline \multirow{2}{*}{$\begin{array}{c}\text { To what extent did } \\
\text { you experience these } \\
\text { constructivist aspects } \\
\text { in RBO? }\end{array}$} & $\begin{array}{c}\text { Very } \\
\text { great } \\
\text { extent }\end{array}$ & $\begin{array}{c}\text { Great } \\
\text { extent }\end{array}$ & Moderate & Little & $\begin{array}{c}\text { Fisher's exact test } \\
\text { for comparison of } \\
\text { the three groups }\end{array}$ \\
\cline { 2 - 6 } & 5 & 12 & 5 & - & $p=0.969$ \\
$\begin{array}{l}\text { Learning situated in } \\
\text { the real world }\end{array}$ & 9 & 9 & 2 & 2 & $p=1.000$ \\
$\begin{array}{l}\text { Discovery learning } \\
\text { Anchored instruction }\end{array}$ & 1 & 11 & 4 & 5 & $p=0.833$ \\
$\begin{array}{l}\text { Active construction of } \\
\text { knowledge }\end{array}$ & 7 & 10 & 3 & 2 & $p=0.245$ \\
Integrated testing & 1 & 10 & 6 & 3 & $p=0.388$ \\
$\begin{array}{l}\text { Transfer to real world } \\
\text { / other studies }\end{array}$ & 8 & 8 & 2 & 3 & $p=0.222$ \\
\hline
\end{tabular}

\section{Personal goals, authenticity, and transfer}

Personal goals were negotiated in the exam projects, as students chose personalized topics and posted proposals for review by peers and course leader. Examples were: pedagogy of teaching history, an interactive web-assessment system, and intranet skills training for industry. The problem drove the learning as learners generated authentic artifacts for use in the workplace. The synergy motivated them to superior efforts in correcting, extending and refining their products. The cooperative-pair tasks were also authentic, for example, evaluations of educational systems. Findings were made available to real-world potential users.

Responding to an open question inquiring which aspect/s of the approach they would use in their own teaching, 11 of the 22 spontaneously mentioned the constructivist/open-ended/group-project features. Seventeen of the participants found the module valuable in their careers:

I'm experimenting with presenting my own material on the Web. /

My institution wants to extend and use my exam project. /

Tough, yet liberating as you had a large say in how you designed work. /

I want to give web-based courses (8 students).

Of the five who did not acknowledge career value, one was a full-time student and three were experienced web designers, for whom the module did not notably increase their expertise. 


\section{Non-simplification}

Table 4 shows that students experienced constructivist frustration (de Villiers 2002) as they encountered cognitive complexity or puzzlement (Perkins 1991b;

Savery and Duffy 1995). Eleven students (half) described initial frustration or challenge, but found it a good way to learn if they persevered. Constructivism via isolated distance-education exacerbated the problem. Students were familiar with constructivist learning from the educator's perspective but once on the receiving end, only seven fully enjoyed the experience. Four of these came from Group 3, who had built websites before. Fisher's exact test comparing the groups with respect to distribution across the categories of 'Impression of constructivist learning' was not significant $(\mathrm{p}=0.537)$. A larger group may have produced a significant result with Group 3 being different, since in Group 3 students mainly 'enjoyed it immensely'; while in Groups 1 and 2 they experienced 'initial frustration/challenge'.

Table 4: The receiving end of constructivism

\begin{tabular}{|c|c|c|c|c|}
\hline \multirow[b]{2}{*}{ Group } & \multirow[b]{2}{*}{$\begin{array}{l}\text { Number of } \\
\text { learners }\end{array}$} & \multicolumn{3}{|c|}{ Impression of constructivist learning } \\
\hline & & $\begin{array}{l}\text { Enjoyed it } \\
\text { immensely }\end{array}$ & $\begin{array}{c}\text { Initial } \\
\text { frustration/ } \\
\text { challenge }\end{array}$ & No comment \\
\hline 1. Novices & 7 & 1 & 5 & 1 \\
\hline 2. Had usedwebsites & 8 & 2 & 4 & 2 \\
\hline 3. Had built websites & 7 & 4 & 2 & 1 \\
\hline Total & $\mathrm{n}=22$ & 7 & 11 & 4 \\
\hline \multicolumn{5}{|c|}{ Fisher's exact $p$-value $=0.537$} \\
\hline
\end{tabular}

\section{Assessment}

Students were assessed by portfolio evaluation, including integrated assessment, self-assessment and 'contracts' between learner and instructor. Schedules were set, since true self-paced work is impractical in a semester module and is incompatible with collaborative learning. Due to workplace demands and deadlines in other courses, students did not always meet the deadlines, which were renegotiated. That in itself was a learning experience, since constructivist learning relates to both the process and the products of learning.

\section{Components}

Components of instruction relate to the basic knowledge, skills and methods of a domain - entailing unitary components and composite components, as well as decontextualized skills. Component Display Theory (CDT) (Merrill 1983) is based 
on relationships between content taught and the level of performance required, examining the goals and instructional strategies of a learning event. Internet-based learning offered no explicit component-based instruction, nor did it teach basic skills. The only form of direct teaching was the inclusion of links to external HTML tutorials. Nevertheless, students were required to use both basic and integrated technical skills, on the assumption that the basics are a pre-existing foundation, which is not always the case. The survey incorporated no explicit questions about components, but in open-ended responses, three of the seven Group 1 students mentioned the value of the tutorials, acknowledging the worth of accessible direct instruction.

\section{Collaborative learning}

Collaborative learning involves joint work, social negotiation, peer evaluation, and the sharing of responsibility in a group, optimising on complementarity and instilling collaborative skills (Nelson 1999; Singhanayok and Hooper 1998). Collaborative tasks are designed in line with Johnson and Johnson's (1991) elements of co-operative learning: a mutual goal, positive interdependence, joint accountability and individual responsibility. Several aspects of the survey related to collaboration and communication. We discuss four aspects:

\section{Whole-group task}

A major task in one presentation was a multimedia 'virtual opera', Phantom of the Internet - a challenging exercise for remote learners. There were complexities in starting, allocating duties, and scheduling, so after two weeks of tentative e-mails and no clear leadership, the module leader who had been 'observing', called a synchronous Chat to consolidate plans. The final artefact was good 'web-ertainment', as students synergistically capitalized on their varied management-, research-, technical and multimedia-, research-, writing- and web-audio skills. As in any teamwork, unequal workload occurred and the group size of eight was cumbersome. Representative responses follow to an open-ended question on the interaction:

The beginning was overwhelming. The first month was sink or swim, initial setting up and straight into the Opera. That was probably why the drop-out rate was high at first. /

The whole group must co-operate, otherwise it delays things. / A simple decision takes days to pan out. /

So "polite", "nice" ... scared to be too forward ... someone has to get started and stick a neck out.

Only four students found online collaborative interaction a fully positive experience. Twelve had mixed feelings and six perceived it negatively. 
It was stressful. I have a strong sense of not wanting to let the side down. This view is not always shared, so meeting the group-goals was not evenly spread out. / It's hard to enforce accountability online. /

It was frustrating . . . we did not all work with the same urgency. /

Working collaboratively without face-to-face contact was a recipe for irresponsibility on my part.

Nevertheless, collaboration brought a sense of community, as students volunteered and allocated roles, capitalizing on strengths and scaffolding weaknesses:

Feeling free to learn from others made me learn more and enjoy the process. / It's exciting to see what is possible and improve it by putting your stamp of individuality on it. /

I offered to be the director and soon we found that the actual task was less daunting than the prospect. /

We delegated tasks, then peer-reviewed our performance in brainstorm sessions. / I appreciate the immense impact of computers on group work. /

My preferred style is autonomy and I am responsible for my successes and failures. When time constraints interfere, I accept this ... But it's harder in groups where group-goals must take precedence. /

I learned lots about . . . creating a climate and community within which to promote Internet learning.

\section{Tasks by two-person teams}

A task undertaken by co-operative pairs involved researching and reporting on existing web-based teaching initiatives, developing an interactive spreadsheet instrument to test web-readiness, and applying it to that initiative. The module leader strategically allocated partners for optimal teamwork. Some experiences were:

I noticed the clever grouping of pairs. /

My partner was under workplace pressure and disappeared into cyberspace!

\section{Ongoing communication via the e-mail forum}

The module leader used this forum for information, instructions and encouragement. Students mainly used it for task-related communication, which varied according to the participants and interpersonal dynamics. Some displayed humour and frivolity; for example, responding to the metaphor by addressing 'Teacher'. They told tales and one played 'truant', replacing her desk with a beach. Such informality evoked reactions and contributed to team spirit. Others preferred just receiving instructions and getting on with the task.

Even online, interpersonal relations can be stressful, and stereotypical class behaviour occurred: conflict, 'bullying', criticism, and taking offence. Reverse 
collaboration took place in the form of tampering with other students' sites (Cronjé 2003), due to material considered offensive towards others' beliefs. In another presentation, 'flaming' (online conflict) erupted between two students due to opposing perceptions on the use of HTML. Acrimonious messages disturbed other students:

Too much irrelevant online bickering /

The learners had to fight it out... (actually an implicit part of the real-world ethos).

The module leader creatively put the duelling students in a 3-member team with a mediator. They built a 'Flames and Internet Wars' website, using a Calvin and Hobbes theme to show how conflict arises.

\section{Membership of an educational technology newsgroup}

Participation in an international newsgroup, ITForum, is compulsory. This further increases the volume of mail. Perceptions ranged widely:

I anticipated each new paper on ITForum. /

Stimulating - I enjoy contributing. / I savoured the daily debate. /

All those e-mails every day ... / Tedious and sometimes irrelevant. / It was irritating ...

I like to get on with a job ASAP in a focused way and interaction interferes ...

\section{Customization}

Customized learning aims for instruction that is learner-centric, adapting to individual profiles, supporting personal learning processes, and granting learners initiative regarding some aspects of the methods, time, place, and content of learning. It supports learner-control, negotiated goals, and the ethos of matching interests and needs within the instructional context (Alessi and Trollip 1991; Bruner 1967; Norman and Spohrer 1996; Reigeluth 1999):

\section{Auto-customisation, constructivist customisation, and customisation of the environment}

Internet-based learning commenced with auto-customisation as students converted their 'desks', some of them into objects that hardly resembled any desk, yet portrayed the student personally. The desk objects (Section 2.3) were hyperlinked to students' own websites. Most important were 'class work' (including links to collaborative projects) and 'portfolio' (individual examination projects).

Constructivist customisation related primarily to human factors underlying learning. Learning was personalized, supporting self-actualisation and selfregulation by making tasks and roles flexible. Students chose the content and context of their examination project so as to gain career value. Ten participants found the module 'fully personalized' to their real-world needs and nine found it 
'personalized to a certain extent'. Regarding preferences for ways of learning, students were asked for open responses naming their preferences and stating whether or not these were met in the module. Eight participants named aspects such as active learning, constructivist learning, trial-and-error, and experiential learning as preferred methods, and all of these eight realized this preference in the module. Further preferences spontaneously mentioned and realized were contextual zed instruction (3 students), practical hands-on activities (2) and open-ended, customisable tasks (3). Another category of responses related to the asynchronous nature of the 'class' and the chance to work independently. Nine explicitly preferred this to rigid learning situations. A distinctive feature of the module is group work within distance learning. Eight of the participants stated that contact with fellow students was a preference. It is notable that, of the eight, four gave it as a preference they had realized and four as one they had not realized. The former found the remote collaboration a positive experience, one describing it as her best-ever experience of teamwork, while the others preferred face-to-face contact With respect to preferences not met, three preferred direct instruction to exploratory learning, and two had missed live debate. One raised the issue of displaying personal skills - feeling that 'techies' with web skills had an advantage, as they customized the module to display technical superiority and graphic design expertise.

Customisation of the environment occurred when a student offered positive criticism of the classroom website. In participatory design, the module leader invited her to help him design the next classroom.

\section{Personal contact with the module leader}

There was consensus that the leader was 'approachable'. Students found him stimulating:

His enthusiasm is pure joy. / He motivates his students.

However, some students had not been sure whether they were on track, because there were no personal messages to individuals nor was there feedback on progress or continuous assessment:

I would like intermediate marks. /

I wasn't bothered by the lack of a mark, but I missed caring interaction . . . such as: 'why aren't you participating?' 'that was good', or 'you are missing the point'.

\section{Creativity}

This evaluation of creativity is conducted last, due to its review of the classroom metaphor and the general approach. Creativity supports the affective aspects of instruction, aiming for novelty within functionality, in ways that motivate learners 
intrinsically. Creative instruction aims to engage learners, to apply innovative strategies, and to strengthen the affective-cognitive bond (Caropreso and Couch 1996; Keller and Suzuki 1988; Price 1998; Wager 1998).

The initial creativity in Internet-based Learning was based on restructuring traditional approaches (De Bono 1970). Whereas in a conventional class about the Internet, students would meet in a laboratory and surf out to sites, in this case, students were isolated and surfed into class. Furthermore, hardly any students were junior schoolteachers. Identifying with the metaphor, therefore, called for simulation and lateral thinking. The authors realize that de Bono's approach is contentious, being concerned 'not with theory, but with practice' and lacking a 'basis in serious psychological theory' (Sternberg and Lubart 1999, 5,6). Yet the survey indicated that students found the module motivational, a finding that can be supported by the 'motivation and creativity' approach, based on 'anecdotal and empirical evidence that creative production does require a high level of motivation' (Collins and Amabile 1999, 297). This approach promotes the maximization of creative potential by allowing people to undertake activities they love, as occurred when students synergistically chose topics relevant to their careers for the exam projects. As stated, eight of the 22 were external students doing other postgraduate programmes who, aware of the content and approach of the module, had registered due to perceived benefits.

\section{Innovative metaphor and motivation}

The metaphor of a junior classroom, its attributes, and means of interpersonal communication (Figure 1) was innovative. In a creative-constructivist ethos, a button concretised the 'Instructor', linking to his personal home page. 'References' opened a 'cupboard' with editors, graphic design utilities and website construction tools. 'Pupils' identified with the informality, personifying their 'desks' and decorating the classroom. Only one was negative regarding the unconventional approach, feeling that the 'frivolous' nature 'undermined credibility'. Others perceived the metaphor as motivating and functional.

In an open unprompted question students were asked to mention features they considered innovative. Their responses are categorized in Table 5, and thematically analysed. Some aspects are closely related to Dick's (1995) conditions for creative instruction, such as creative and relevant activities, matching of interests, and innovative use of technologies. The statement in Table 5: ' . . . the first time I had experienced this kind of interaction in a learning environment' is notable, particularly for a distance-learning context. The next question inquired what aspect/s students had used, or planned to use, in their own teaching. Six mentioned online forums, six named constructivism or open-ended assignments, three highlighted group work, and two required online portfolios from their learners. A teacher who had newly given his pupils open-ended projects had been surprised by their initiative. Only one explicitly intended not to 'use any of those aspects'. 


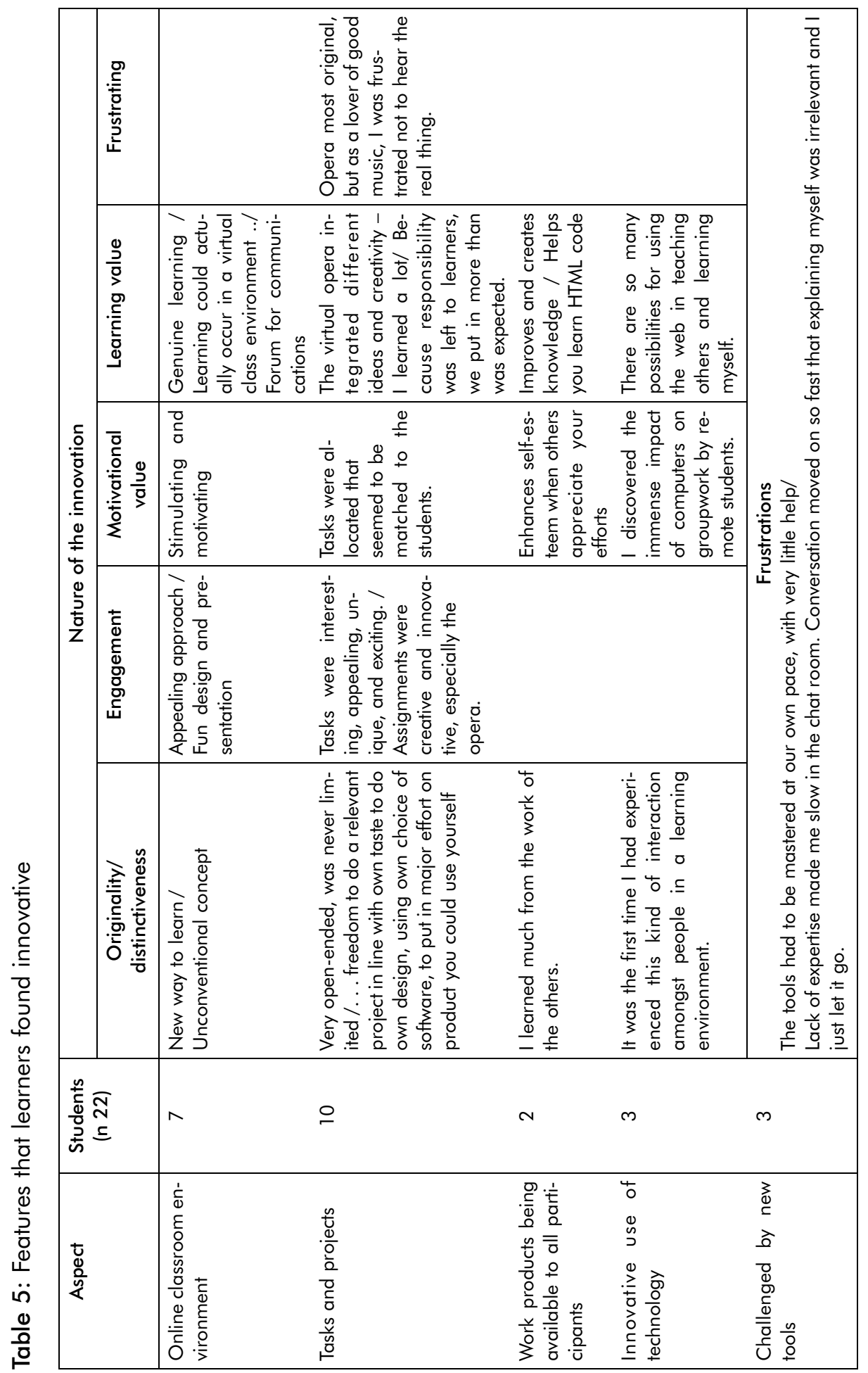




\section{Creativity and generativist in students}

Class behaviour showed students' creativity or lack thereof. Personalities played roles as students respectively joked, challenged, questioned, responded, hardly participated, criticized, quarrelled, or were mischievous. Role-play elicited reactions and helped develop class spirit. Finally, the quantity and standard of work products indicated commitment. Classroom objects proliferated with each presentation; students linked projects to the poster wall along with previous years' efforts. The blackboard became a graffiti wall - for fun or personal agendas. Creativity engendered creativity and enthusiasm among the students - in the content and presentation of their tasks, and particularly in the quality and extent of examination projects.

\section{Engagement}

Finally, when asked about activities that engaged them, some described experiencing flow (Csikszentmihalyi 1990) - being 'glued to the computer' and 'working more than intended'. Regarding joint projects, despite the obstacles, students found them stimulating and rewarding as the multimedia productions grew and their own contributions were inserted.

\section{LESSONS LEARNED: ANALYSIS OF THE FINDINGS}

To consolidate this article, we compiled two thematic matrices (Miles and Huberman 1994) focussing, respectively, on strengths and on problems. The first matrix lists strengths identified by the evaluation in the left column and associates them with their underlying cause/s, placed directly to the right. Generic principles can be induced from the strengths.

\begin{tabular}{|l|l|}
\hline Strengths identified in Internet-based learning & Associated cause \\
\hline $\begin{array}{l}\text { Constructivist aspects } \\
\text { A high degree of independent work by adult } \\
\text { distance-learners. Most of those with little }\end{array}$ & $\begin{array}{l}\text { Mature, self-motivated learners were able } \\
\text { to overcome obstacles and work indepen- } \\
\text { initial technological expertise managed to } \\
\text { bridge the gap and became confident web }\end{array}$ \\
$\begin{array}{l}\text { designers. } \\
\text { system. }\end{array}$ \\
$\begin{array}{l}\text { Concretized discovery learning leading to } \\
\text { retention and transfer to the real world and } \\
\text { the workplace. Those who persevered, } \\
\text { generated work that contributes to authentic buddy } \\
\text { domains. }\end{array}$ & $\begin{array}{l}\text { tive. Due to the explicit intention not to } \\
\text { simplify, few students actually enjoyed the } \\
\text { constructivist approach, yet most performed } \\
\text { well and retrospectively acknowledged its } \\
\text { value. }\end{array}$ \\
\hline
\end{tabular}




\section{Cognitive learning aspects}

Educators became learners, undertaking meta-learning (i.e. learning about learning).

Incorporated various means of learning conceptual and practical; analysis and synthesis.

Fostered self-regulation, planning and monitoring.
Reflection on one's own learning enhances empathy with one's pupils/students.

Effective web development entails theoretical and practical expertise, as well as time management.

Investigating existing web-learning initiatives and assessing peers' projects honed evaluative skills and analytical abilities.

For those accustomed to computing, e-mail contact is a natural extension of verbal communication. Electronic interaction can replace $f-2-f$ contact in a way that reduces inhibitions and supports expression of emotion.

Distance-collaboration exacerbates the problems of teamwork. Having experienced planning, scheduling, monitoring, work allocation, accountability, etc. in distancesituations, participants can build better face-to-face teamwork.

The leader capatalized on strengths and compensated for gaps. teams.

\section{Customization}

Flexible and adaptable approach. Auto-customization (self-customization). Learning personalized to match preferences and offer career relevance.

Module design was learner-centric and supported learner-control.

Projects/artifacts were customisable, and so was the approach.

The exam project was open-ended both in content and context.

The enthusiasm of the module leader communicated itself to the learners, stimulating their efforts.

Creative tasks motivated the learners, fostering enthusiasm, innovation and diligence.

The second matrix lists issues/problems on the left and associated recommendations to their right. Some aspects appear both as a strength in the first matrix and as a problem in this, due to their impact on different learners. 


\begin{tabular}{|c|c|}
\hline Issues and problems & Recommendations / palliative strategies \\
\hline $\begin{array}{l}\text { Constructivism } \\
\text { Constructivist frustration and cognitive } \\
\text { complexity. }\end{array}$ & $\begin{array}{l}\text { Reduce quantity of work, yet maintain } \\
\text { complexity. } \\
\text { Provide a bridging course where required. }\end{array}$ \\
\hline $\begin{array}{l}\text { Cognitive learning } \\
\text { High initial attrition - four of the eleven who } \\
\text { discontinued did so due to low technical } \\
\text { expertise. } \\
\text { Some worked slowly in building their web- } \\
\text { products. }\end{array}$ & $\begin{array}{l}\text { Though it was made clear that the module } \\
\text { does not teach basic skills and there is no } \\
\text { direct instruction (apart from external linked } \\
\text { tutorials), a systematic module on technical } \\
\text { web development should be available, as } \\
\text { well as optional graphics instruction. This } \\
\text { would reduce learning curves and support } \\
\text { integration of new with prior learning. }\end{array}$ \\
\hline $\begin{array}{l}\text { Time-consuming. Some students experi- } \\
\text { enced overload. }\end{array}$ & $\begin{array}{l}\text { Note the two recommendations above, as } \\
\text { well as the last problem and recommen- } \\
\text { dation in this matrix. }\end{array}$ \\
\hline $\begin{array}{l}\text { Online collaborative learning } \\
\text { Start-up: Complications in commencing } \\
\text { joint projects. Indecisiveness and procrasti- } \\
\text { nation led to delays until leading roles were } \\
\text { defined. }\end{array}$ & $\begin{array}{l}\text { Where learners do not know one another, } \\
\text { instructors/course leaders should be pro- } \\
\text { active in facilitating start-ups and the } \\
\text { appointment of leaders. }\end{array}$ \\
\hline $\begin{array}{l}\text { Lack of urgency: Particularly evident in early } \\
\text { presentations where all communication was } \\
\text { asynchronous. }\end{array}$ & $\begin{array}{l}\text { Chat sessions partially address this, pro- } \\
\text { viding synchronous interaction and ur- } \\
\text { gency. }\end{array}$ \\
\hline $\begin{array}{l}\text { Group size: eight was too large for online } \\
\text { collaboration. }\end{array}$ & Four would be optimal. \\
\hline $\begin{array}{l}\text { Customization } \\
\text { No comments or grades on projects, other } \\
\text { than feedback on exam project proposals. } \\
\text { Students obtained opinions from fellow- } \\
\text { learners due to the visibility of products, but } \\
\text { some felt insecure without a 'mark'. }\end{array}$ & $\begin{array}{l}\text { There should be interim grading, so that } \\
\text { students commence the exam project } \\
\text { knowing their 'semester mark'. }\end{array}$ \\
\hline $\begin{array}{l}\text { Components } \\
\text { Some knowledge and skills would have } \\
\text { been better learned via direct instruction. }\end{array}$ & $\begin{array}{l}\text { Knowledge/skills in website development } \\
\text { should be a prerequisite. }\end{array}$ \\
\hline $\begin{array}{l}\text { Creativity } \\
\text { Websites developed by 'techie' students } \\
\text { included special effects and animations. } \\
\text { These enhanced the classroom and could } \\
\text { be considered a strength, but are men- } \\
\text { tioned here to caution against distraction or } \\
\text { detracting from the main purpose. }\end{array}$ & $\begin{array}{l}\text { Creativity - by educator or learners - must } \\
\text { remain supplementary to learning. Hi-tech } \\
\text { effects should be used solely in support of } \\
\text { information communicated, i.e. as a med- } \\
\text { ium, not the message. }\end{array}$ \\
\hline $\begin{array}{l}\text { 'Flow', also a strength, resulted in some } \\
\text { students overextending themselves, delay- } \\
\text { ing teamwork and causing overload or } \\
\text { extending durations. }\end{array}$ & Deadlines should be enforced. \\
\hline
\end{tabular}




\section{CONCLUSION}

The learner evaluation showed that the Internet-based Learning module simulated a real-world class, its actions, ethos, and interaction in a way that creatively implemented constructivist learning and distance-collaboration. Different course presentations involved different personalities, different group dynamics, and varying tasks, providing further insights. Use of the $\mathrm{HCMm}$ as an inquiry framework provided structure for evaluations and retrospective reflection, showing that course strengths are closely related to its implementation of the C-elements, while also revealing problems and issues. Constructivist learning has its challenges - for educator and learners alike, but even more so in the case of constructivist distance collaboration, which brings its own blend of complexities, since a virtual class cannot be equated with contact learning. These were categorized and palliative measures recommended.

Entry-level expertise ranged widely, from Internet novice (Group 1) through Internet use (Group 2) to those with prior web-design skills (Group 3). Despite the discrepancies, the novices who persevered overcame the barriers and evidenced learning gain, attested to by their final percentages and survey responses. Where Likert scale scores and open-ended answers were statistically compared between groups, there were no significant differences.

As Internet-based learning becomes increasingly common and as constructivist design matures, further research is required into how to address issues identified, for example, mechanisms for supportive feedback, the development of online learning cultures, and the frustration inherent in constructivist distance-learning.

\section{ACKNOWLEDGEMENT}

The authors acknowledge contributions from the students who participated in the survey.

\section{REFERENCES}

Alessi, S. M. and S. R. Trollip. 1991. Computer-based instruction: methods and development. Englewood Cliffs, N.J.: Prentice Hall.

Bruner, J. S. 1967. Toward a theory of instruction. Cambridge Mass: Harvard University Press. Caropreso, E. J. and R. A. Couch. 1996. Creativity and innovation in instructional design and development: the individual in the workplace. Educational Technology 36(6):31-39.

Collins, M. A. and Amabile, T. M. 1999. In Handbook of creativity, ed. Sternberg, R. J. Cambridge: Cambridge University Press.

Cronjé, J. C. 2001. Metaphors and models in Internet-based learning. Computers and Education 37(3-4): 241-256.

- 2003. The virtual Halloween: Cyber conflict in a virtual learning community. Proceedings of Ed-Media 2003 World Conference on Educational Multimedia, Hypermedia and Telecommunications. 
Cronjé, J. C. and P. A. Clarke. 1999. Teaching "teaching on the Internet" on the Internet. South African Journal of Higher Education 13(1):213-226.

Czikszentmihalyi, M. 1990. Flow: The psychology of optimal experience. New York: Harper and Row.

De Bono, E. 1970. Lateral thinking: a textbook of creativity. Harmondsworth: Penguin Books.

De Villiers, M. R. 1999. Applying the Hexa-C Metamodel of instructional theory and design to educational web applications. In Proceedings of Web Net 99 - World Conference on the $W W W$ and Internet, eds. De Bra, P. and J. Leggett. Honolulu: Association for the Advancement of Computing in Education.

- 2000. Evaluation of an interactive learning environment: theory and practice. South African Journal of Higher Education 14(3):120-131.

- 2002. The dynamics of theory and practice in instructional systems design. Unpublished $\mathrm{PhD}$ dissertation, Pretoria: University of South Africa.

- 2003. Foundation for structure: a learning theory approach to instructional design for elearning. International Journal of Learning Vol 10, 2003. What learning means. Proceedings of the Learning Conference. Common Ground Publishing. (Online). Available at: http:// LearningConference.Publisher-Site.com/.

De Villiers, M. R. and D. R. Queiros. 2003. Real-world problem based learning: a case study evaluated. South African Journal of Higher Education 17(1):112-122.

Dick, W. 1995. Instructional design and creativity. Educational Technology 35(4):5-11.

Duffy, T. M. and D. H. Jonassen. 1991. Constructivism: new implications for instructional technology? Educational Technology 31(5):7-12.

Gagné, R. M. and M. D. Merrill. 1990. Integrative goals for instructional design. Educational Technology Research and Development 38(1):23-30.

Inhelder, B. and J. Piaget. 1958. The growth of logical thinking from childhood to adolescence. New York: Basic Books Inc. Publishers.

Keller, J. M. and K. Suzuki. 1988. Use of the ARCS motivational model in courseware design. In: Instructional designs for microcomputer courseware, ed. Jonassen, D. H. New Jersey: Lawrence Erlbaum Associates.

Johnson, D. W. and R. T. Johnson. 1991. Learning together and alone. Englewood Cliffs, N.J.: Prentice Hall.

Jonassen, D. 1999. Designing constructivist learning environments. In Instructional-design theories and models: A new paradigm of instructional theory. Volume II, ed. Reigeluth, C. M. Mahwah, N.J.: Lawrence Erlbaum Associates.

Land, S. M. and B. A. Greene. 2000. Project-based learning with the World Wide Web: A qualitative study of resource integration. Educational Technology Research and Development 48(1):45-68.

Merrill, M. D. 1983. Component display theory. In Instructional design theories and models: An overview of their current status, ed. Reigeluth, C. M. Hillsdale, N.J: Lawrence Erlbaum Associates.

Miles, M. B. and Huberman, M. 1994. An expanded source book: Qualitative data analysis. $\left(2^{\text {nd }}\right.$ Edition). London: Sage Publications.

Nelson, L. M. 1999. Collaborative problem solving. In Instructional-design theories and models: A new paradigm of instructional theory. Volume II, ed. Reigeluth, C. M. Mahwah, N.J: Lawrence Erlbaum Associates.

Newell, A. and H. A Simon. 1972. Human problem solving. Englewood Cliffs, N.J: PrenticeHall Inc. 
Norman, D. A. and J. C. Spohrer. 1996. Learner-centered education. ITForum Paper \#12. (Online). Available at http://it.coe.uga.edu/itforum/paper12/paper12.html.

Osman, M. E. and M. J. Hannafin. 1992. Metacognition research and theory: analysis and implications for instructional design. Educational Technology Research and Development 40(2):83-99.

Perkins, D. N. 1991a. Technology meets constructivism: do they make a marriage? Educational Technology 31(5):18-22.

- 1991b. What constructivism demands of the learner. Educational Technology 31(9):1921.

Price, E. A. 1998. Instructional systems design and the affective domain. Educational Technology 38(6):17-28.

Reigeluth, C. M. 1999. What is instructional-design theory and how is it changing? In Instructional-design theories and models: A new paradigm of instructional theory. Volume II, ed. Reigeluth, C. M. Mahwah, N.J: Lawrence Erlbaum Associates.

Savery, J. R. and T. M. Duffy. 1995. Problem based learning: an instructional model and its constructivist framework. Educational Technology 35(5):31-38.

Singhanayok, C. and S. Hooper. 1998. The effects of cooperative learning and learner control on students' achievement, option selections, and attitudes. Educational Technology Research and Development 46(2):17-33.

Sternberg, R. J. and T. I. Lubart. 1999. The concept of creativity: prospects and paradigms. In Handbook of creativity, ed. Sternberg, R. J. Cambridge: Cambridge University Press.

Wager, W. 1998. Social determinants of affective behavior and learning. Educational Technology 38(6):15-16.

Willis, J. 2000. The maturing of constructivist instructional design: some basic principles that can guide practice. Educational Technology 40(1):5-16.

Winn, W. 1990. Some implications of cognitive theory for instructional design. Instructional Science 19(1):53-69.

1992. The assumptions of constructivism and instructional design. In Constructivism and the technology of instruction: a conversation, eds. Duffy, T. M. and D. H. Jonassen. Hillsdale, N.J.: Lawrence Erlbaum Associates. 